\title{
Przegląd orzecznictwa Sądu Najwyższego z zakresu kodeksu spółek handlowych w 2018 r.
}

\author{
Case Law of the Supreme Court in the Field \\ of Commercial Companies Code in 2018
}

\author{
dr Tomasz Szczurowski
}

E-mail: t_szczurowski@uksw.edu.pl; ORCID: 0000-0002-2967-0919

\begin{abstract}
Streszczenie
Przedmiotem artykułu jest analiza najważniejszych wydanych w 2018 r. orzeczeń Sądu Najwyższego. Zaprezentowane orzeczenia przede wszystkim dotyczą tematyki objętej kodeksem spółek handlowych. Odnoszą się one do tak istotnych zagadnień, jak: postępowanie przymuszające, sukcesja po spółce osobowej rozwiązanej bez likwidacji, ugoda mediacyjna, zaskarżanie uchwał zgromadzeń wspólników, czas właściwy do ustalenia niedozwolonego postanowienia umownego, odpowiedzialność za zobowiązania w kontekście podziału spółki przez wydzielenie. Autor najpierw cytuje fragmenty orzeczeń, a następnie opatruje je krótkim komentarzem.
\end{abstract}

Słowa kluczowe: Sąd Najwyższy, orzecznictwo

\section{Summary}

The article presents the most important judgements rulled by The Supreme Court in 2018. The judgements treats topics which are real important for business activity. Most of the judgements are based on The Commercial Companies Code. They headlights problems with compulsory proceedings, succesion after partnerships when partner agreed on another manner of closing the partnership's business than liquidation, mediation agreements, appealed against resolution of the shareholders, time to determine unfair contractual terms, liability for obligation under division by separation. The author quotes the judgments and comments them.

Key words: The Supreme Court, judgement

JEL: K2

Str. 36-44

\section{Bibliografia}

Szczurowski, T. (2019). Zastosowanie art. 210 Kodeksu spółek handlowych przy zmianie umowy spółki komandytowej, Przegląd Ustawodawstwa Gospodarczego (1), s. 31.

\section{Akty prawne}

Dyrektywa Rady 93/13/EWG z 5.04.1993 r. w sprawie nieuczciwych warunków w umowach konsumenckich (Dz. Urz. WE L 95, s. 29, ze zm.) - dyrektywa 93/13.

Konstytucja Rzeczypospolitej Polskiej z 2.04.1997 r. (Dz.U. nr 78, poz. 483 ze zm.)

Ustawa z 23.04.1964 r. — Kodeks cywilny (Dz.U. z 2018 r. poz. 1025 ze zm.) - k.c.

Ustawa z 17.11.1964 r. — Kodeks postępowania cywilnego (Dz.U. z 2018 r. poz. 1360 ze zm.) — k.p.c.

Ustawa z 16.09.1982 r. — Prawo spółdzielcze (Dz.U. z 2018 r. poz. 1285 ze zm.).

Ustawa z 29.09.1994 r. o rachunkowości (Dz.U. z 2019 r. poz. 351 ze zm.).

Ustawa z 20.08.1997 r. o Krajowym Rejestrze Sądowym (Dz.U. z 2018 r. poz. 986 ze zm.) — ustawa o KRS. 
Ustawa z 15.09.2000 r. — Kodeks spółek handlowych (Dz.U. z 2019 r. poz. 505 ze zm.) — k.s.h.

Ustawa z 28.07.2005 r. o kosztach sądowych w sprawach cywilnych (Dz.U. z 2019 r. poz. 785) — u.k.s.c.

\section{Orzeczenia sądowe}

Postanowienie TS z 11.06.2015 r., C-602/13, Banco Bilbao Vizcaya Argentaria, SA v. F. Quintano Ujeta i M. I. Sánchez García, EU: C: 2015: 397.

Uchwała SN z 11.01.2018 r., III CZP 90/17, LEX nr 2425004.

Uchwała SN z 23.02.2018 r., III CZP 88/17, LEX nr 2445073.

Uchwała SN (7) z 20.06.2018 r., III CZP 29/17, LEX nr 2504739.

Uchwała SN z 7.09.2018 r., III CZP 42/18, LEX nr 2541937.

Wyrok SN z 9.02.2018 r., I CSK 241/17, LEX nr 2483684.

Wyrok SN z 24.04.2018 r., V CSK 425/17, LEX nr 2500433.

Wyrok SN z 6.06.2018 r., III CSK 403/16, LEX nr 2557164.

Wyrok SN z 14.06.2018 r., V CSK 514/17, LEX nr 2511921.

Wyrok SN z 6.07.2018 r., II CSK 617/17, LEX nr 2518911.

Wyrok SN z 14.12.2018 r., I CSK 687/17, LEX nr 2600070. 